\title{
Following Only Some of the Money in Russia
}

Ethan S. Burger

Georgetown University Law Center, esb34@law.georgetown.edu

This paper can be downloaded free of charge from:

https://scholarship.law.georgetown.edu/facpub/167

Demokratizatsiya, Winter 2009, at 41-70

This open-access article is brought to you by the Georgetown Law Library. Posted with permission of the author. Follow this and additional works at: https://scholarship.law.georgetown.edu/facpub

3 Part of the Criminal Law Commons, International Law Commons, and the Law and Economics Commons 


\title{
GEORGETOWN LAW Faculty Publications
}

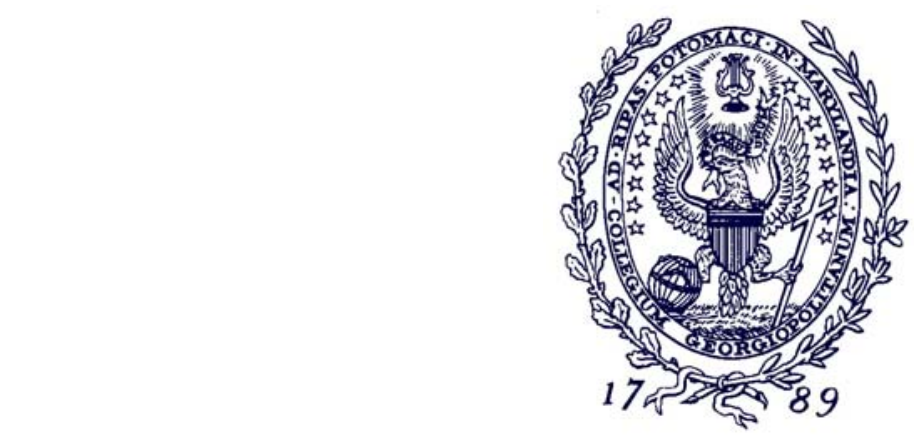

Georgetown Business, Economics \& Regulatory Law Research Paper No. 10-01 January 2010

\section{Following Only Some of the Money in Russia}

\author{
Demokratizatsiya, Winter 2009, at 41-70
}

\author{
Ethan S. Burger \\ Professor of Law \\ Georgetown University Law Center \\ esb34@law.georgetown.edu
}

This paper can be downloaded without charge from:

Scholarly Commons: http://scholarship.law.georgetown.edu/facpub/167

SSRN: http://ssrn.com/abstract $=1543240$

Posted with permission of the author 


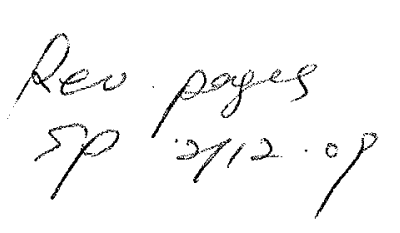

\title{
Following Only Some of the Money in Russia
}

\author{
ETHAN S. BURGER, ESQ.
}

\begin{abstract}
Since 1998, Russia has not developed an effective anti-money-laundering (AML) system. The country has the legal framework and institutions for combating rnoney laundering, but Russia continues to experience a high level of capital flight of illicit funds. Although it is impossible to precisely estimate the amount of money that has circumvented Russia's currency control system, it is probably approximately $\$ 7$ billion. In this article, the author discusses some of the many reasons that Russia has had difficulty establishing an effective AML system.

One reason is that it may be easier to launder money out of Russia than many other countries. Its banking sector is not well developed; many Russian banks exist simply to service the large enterprises that own them. At the same time, the country's regulators lack sufficient personnel, material assets, and political support to limit the high levels of illegal capital flight. Other contributing factors include Russian enterprises that circumvent transfer pricing rules through complex related-party transactions, pervasive governmental corruption, highly sophisticated organized crime groups, economic instability, and a limited commitment on the part of law enforcement to apply AML rules uniformly. This situation is unlikely to change in the foreseeable future, and, given the large amount of money involved, the Russians engaged in money laundering are assured that foreign individuals and organizations eager to profit from the process will assist them.
\end{abstract}

Keywords: anti-money-laundering systems, corruption, currency control, Financial Action Task Force, financial crime, flight capital, money laundering, RosFinMonitoring

$\mathbf{T}^{\mathrm{t}}$ he Russian state bodies and personnel assigned to implement the country's anti-moneylaundering (AML) policies seem to have allowed the Russian political leadership and its principal allies to move large shares of the wealth they have acquired during the Putin era abroad. Although some of this wealth was accumulated illegally, a great deal of it is the result of activity that is allowed in Russia but prohibited in most economically advanced

Ethan S. Burger is a specialist on international economic crime and corruption, which he teaches about at the Georgetown University Law Center. He serves as senior counsel at the law firm Maxwell \& Barke, LLC. He has been an expert witness in numerous financial crime matters (e.g., FCPA, ML, RICO) and given numerous presentations on these matters. He has spent a majority of his legal career dealing with Russian economic crime, investment, and trade issues. Copyright (C) 2009 Heldref Publications 
countries, such as insider trading. As is the case with Russian criminal and regulatory enforcement agencies, the Russian Federal Monitoring Service (RosFinMonitoring) ${ }^{1}$ and other relevant state bodies selectively enforce AML policies, focusing on low-level and mid-level officials and businesspersons who do not enjoy high-level political patrons.

\section{Why Money Is Laundered and How It Is Related to Corruption}

Traditionally, money laundering is an important element of the ability of corrupt government officials and their allies to profit from their political power-that is, officials use the process to treat the state as their own private property. In Russia, political and economic elites often act with impunity when they violate their country's laws, because they know that they will not be investigated or prosecuted for their illegal activities.

Generally, money laundering is conceptually divided into three distinct stages or phases. According to the United Nations Office on Drugs and Crime, these three stages are placement, layering, and integration, but these are best viewed as one process. The placement stage represents the initial entry of the proceeds from crime into the financial system. This stage serves two purposes - it relieves the criminal of holding and guarding the large physical bulk of cash and places the money in the legitimate financial stream. Layering is the process of separating the capital from their illegal source. During the integration stage, the earnings are converted into apparently legitimate earnings. The placement stage is considered to be the riskiest, for it is then that the chances of raising suspicion are the greatest. ${ }^{2}$

A working AML system should have the ability to detect illicit funds at each point in the process. To "follow the money," AML personnel must be able to operate domestically and internationally. When operating abroad, they normally must have good working relations with other financial intelligence units. ${ }^{3}$

\section{The Evolution of Russian Currency and Anti-Money-Laundering Policies}

In 1992, the Russian State Duma assigned the responsibility for the regulation and control of foreign currency to the Central Bank of the Russian Federation (RCB) pursuant to the Law on Hard Currency Regulation and Control. ${ }^{4}$ This piece of legislation was a framework law empowering the RCB to issue detailed rules covering transactions between Russians and foreign persons. The RCB is nominally independent from the executive branch, with foreign economic policy under the control of the Russian Ministry of Finance.

Since the enactment of the Law on Hard Currency Regulation and Control, the volume of Russian trade has grown exponentially and governmental officials have become more familiar with international finance. This has led to fewer requirements in certain areas, decentralization in some regulatory responsibilities, and greater sophistication within the government on foreign economic relations. In recent years, the RCB's authority has become more limited, with the Russian governmental bodies responsible for collecting taxes and customs duties assuming responsibility for areas formerly under RCB auspices. Compared with the central banks in other countries, the RCB seems to have less autonomy. At times, it seems as if the Russian political leadership treats the RCB as if it were an executive body.

Despite the growing internationalization of the finance sector, it was not until August 7 , 2001 , that Russia finally enacted a law making money laundering a criminal offense. ${ }^{5}$ However, under Russian law, until an offense is added to the Criminal Code of the Russian 
Federation, it is not considered to be enforceable. ${ }^{6}$ This did not immediately happen for the 2001 law; thus, the new Russian AML rules did not go into effect for more than one year. In many regards, then, the Russian government adopted the legal framework for combating money laundering used by most industrial countries but it did not put that framework into action. ${ }^{7}$

When the Russian government has taken steps to combat money laundering, the RCB has followed its lead and paid greater attention to banks suspected of facilitating money laundering, such as those involving small charter capitals. Of late, Russian banks have been more scrupulous in examining Russian companies' transactions with entities located in countries in former Soviet states and in Cyprus, but this is a relatively recent phenomenon. It appears as if the Russian government, the $\mathrm{RCB}$, and private banks lack the resources (and determination) to ensure compliance with the applicable AML rules. On November 28, 2007, the Russian State Duma amended Russian Federal Law No. 115-FZ On Countering the Legalization of Illegal Earnings and the Financing of Terrorism. Some of the law's changes seem aimed at further decreasing the chances that members of the Russian political leadership or its favored allies would be prosecuted for money laundering. ${ }^{8}$

According to specialists on the Russian banking sector, only about 300 of the 1,200 licensed banks in Russia are "real banks." A majority of the remainder have been characterized as "little more than treasuries for big businessmen or engaged in criminal activity such as money laundering."' Deputy Prime Minister Igor Shuvalov has said that he foresees the number of banks in the country possibly decreasing to as few as $100 .{ }^{10}$ The banks that would survive under this scenario would be state-controlled banks, such as Open Joint Stock Company (OAO) Sberbank, ${ }^{11}$ OAO Bank VTB (Foreign Trade Bank), VEB (Foreign Export Bank), and Gazprombank. The remaining banks would constitute about 40 percent of Russian banking/apprarently in private hands. ${ }^{12}$ According to the Alinga Consulting Group, a recent amendment to the Russian Law on Banking and Banking Activity that raises the minimum capital requirements for a banking licence is likely to lead to roughly 400 banks losing their licenses. ${ }^{13}$

The RCB has the authority to revoke banking licenses. It would be instructive to see what criteria are used. According to RCB chairperson Sergey Ignatiev, already more than fifty Russian banks have failed because of the 2008 financial crisis. Since Ignatiev's appointment, the RCB has issued banking licenses to Russian banks permitting them to engage in banking opportunities, and he is in a position to close banks for financial reasons or for not complying with Russian legislation, including involvement in money laundering. ${ }^{14}$ This again raises the issue of selectivity. The subject of favoritism also arises when examining which banks receive state funds during the bank crisis.

RosFinMonitoring is an executive body that reports to the prime minister and works in conjunction with the Ministry of Finance and other state bodies. Its status has been formalized persuant to presidential edicts. ${ }^{15}$ This means that RosFinMonitoring's head reports to an official who holds his position at the pleasure of the Russian president. This stauts is potentially important to those engaged in economic crime because individuals could not be charged with money laundering, but instead only for the underlying offense, such as tax evasion. ${ }^{16}$

It is difficult to make a comprehensive assessment of the effectiveness of RosFinMonitoring. For example, in 1997, Russian minister for the interior Vladimir Lyukanov reported that there were " 22,500 fly-by-night firms involved in money laundering schemes. These 
companies were involved in schemes to expatriate capital abroad as well as in illegal cashing and tax evasion." 17 According to Lyukanov, these entities had been established by at least 137 organizations and individuals, whose actions generated at least 6,000 criminal investigation. ${ }^{18}$ Many instances of money laundering involved the use of fictitious contracts to move money. It is likely that these cases were never prosecuted.

In August 2008, RosFinMonitoring hosted the Russian Inter-Departmental Commission for Combating Terrorism. RosFinMonitoring wished to amend the Law on the Central Bank to allow the regulator to issue fines against banks not complying with applicable AML regulations rather than merely issuing warnings for violations, such as the failure to file complete Suspicious Transaction Reports, which are reports that banks must file with RosFinMonitoring if they suspect that their customers are engaged in money-laundering activities.

RosFinMonitoring also proposed that senior bankers be fined individually if their banks did not observe AML rules and that the RCB have the right to make an unlimited number of inspections of banks suspected of money laundering. Not surprisingly, many bank officials want to limit the RCB's ability to conduct inspections to a small, fixed number. ${ }^{19}$ The amendments that are ultimately adopted may reveal the power of banks to operate as an effective interest group ${ }^{20}$ and whether bank regulators are willing and able to obtain expanded powers. ${ }^{21}$

\section{The Russian Banking Sector}

In the aftermath of major declines in the value of the Russian stock market, large-scale capital flight from Russia after the invasion of Georgia, ${ }^{22}$ and the global financial crisis, the Russian banking sector has become increasingly unstable. ${ }^{23}$ The Russian Ministry of Finance announced that it was extending a three-month emergency credit in an amount of $\$ 17.06$ billion, with an additional $\$ 24.21$ billion to more than twenty-five private banks, whereas in the past, it has limited its involvement to state-controlled banks such as Sberbank, VEB, VTB, and Gazprombank. ${ }^{24}$ Uncharacteristically, VET acquired a 98 percent position in the financially troubled Svyaz-Bank. ${ }^{25}$ The RCB took action to increase financial liquidity in the country by reducing bank reserve requirements. ${ }^{26}$

In late September 2008, the Association of Russian Banks approached the RCB, hoping to obtain a moratorium on the revocation of banking licenses for financial institutions that failed to comply with more demanding rules set forth in Article 7 of the Russian Law Concerning the Identification of Persons Wiring Funds to and from Russia, which went into force on October 1, 2008. ${ }^{27}$

Fearing the consequences of numerous Russian banks losing their operating licenses, RosFinMonitoring and the association worked together to produce draft amendments to the law. However, the Duma did not approve these amendments before the expiration of the moratorium. Nonetheless, the RCB, fearing a further loss of public confidence in the banking sector, chose to grant the requested extension until April 2009 in the hope of avoiding another financial crisis. Not surprisingly, the banking community was relieved by the RCB's decision. ${ }^{28}$

It is not clear why the RCB adopted an across-the-board moratorium. It would seem that the central bank missed a golden opportunity to revoke the banking licenses of approximately 900 entities that Russian officials have already indicated are not "real banks," meaning that Russia could have eliminated many banks that were simply fronts with negligible economic impacts. It remains to be seen whether the RCB will systematically take such action in the future. 


\section{Evaluating Russia's AML Efforts (When the Russian Government Is the Client)}

Russian businesspersons are known to have established legal entities abroad that can be used to cover up money laundering. ${ }^{29}$ When the Russian government demurs at strictly applying applicable banking regulations, the $\mathrm{RCB}$ seems willing to act in a manner consistent with the Russian government's wishes. ${ }^{30}$ This is not meant to suggest that the RCB's AML operations are highly effective. Deloitte \& Touche recently completed a study evaluating the RCB's AML activities, at the RCB's request. The study concluded that:

- Russian practice, in comparison with world practices, is excessively formalized. This suggests that the RCB's focus is on bureaucratic activity, rather than producing results. For example, Russian banks file a greater number of suspicious activities reports than banks in Britain, Switzerland, and the United States. This behavior may overwhelm Russian government authorities with information of little value. ${ }^{31}$

- Russia's AML procedures provide

"For Russia's [anti-money-laundering] operations to be effective, there must be a sufficient number of trained individuals not only in the government, but within banks and other commercial enterprises." a high level of detailed guidance, which is reflected in the country's legislation. Russian banks have a "passive role" in collecting and maintaining information required by applicable rules to the detriment of a more flexible objective-oriented approach in which the banks proactively work with regulators.

- Russian banks cannot deny services to potential customers at their own initiative.

- Russian AML activities might be more effective if RosFinMonitoring and the RCB operated competitively rather than in a complementary manner. ${ }^{32}$

For Russia's AML operations to be effective, there must be a sufficient number of trained individuals not only in the government, but within banks and other commercial enterprises. Otherwise, there is a risk that important information is missed or not examined in a timely manner (if at all), the full potential of software is not used, and procedures established by the government and by private institutions are not followed..$^{33}$ According to RosFinMontoring's Web site, in April 2008, it had only five vacancies, and none were positions for AML specialists. The Moscow Times reported:

The report also recommended "substantially" expanding staff at the Federal Service for Financial Markets, the Federal Insurance Supervision Service and the Federal Communications Agency. ${ }^{34}$

Other recommendations included preventing criminals from owning large stakes in banks and other financial institutions. The report said holders with a 10 percent stake or more, instead of the current 20 percent, should be subject to checks. It also suggested that Russia criminalize insider trading and market manipulation. ${ }^{35}$

As a result of the personnel and other shortcomings in the Russian AML system, the number of AML cases brought by the procuracy involving large amounts of money was 
relatively low. The most prominent cases involving money laundering are deemed by many to be politically motivated, as was the case with Boris Berezovsky, Mikhail Gutseriev, and Mikhail Khodorkovsky, with the limited exceptions of Russian officials convicted abroad for money laundering, such as Pavel Borodin. ${ }^{36}$ Although Russian government officials are quick to cite the increased number of prosecutions and money-laundering cases opened, including at least one conviction at the ministerial level, no one with close relations to Putin has been convicted of a crime..$^{37}$

\section{Not All Money Launderers Are Created or Treated Equally}

A key aspect of Putin's consolidation of power involved obtaining direct or indirect control over the country's natural resources, primarily its energy assets. ${ }^{38}$ This occurred concurrently with Putin's transference of considerable power from the Russian legislature and regional authorities to the presidential administration and the power ministries, principally the Federal Security Bureau (FSB) and the Ministry for Interior (MVD). ${ }^{39}$ The highest officials within these organizations are frequently referred to as the siloviki.

Russians voiced little concern when Putin asserted control of the nation's natural resources, and they supported the president, seeing his policies as the restoration of order and prosperity ${ }^{40}$ However, the appearance of law and order was a mere mirage; corruption in Russia skyrocketed. Transparency International, a global corruption monitor, ranked Russia 143 out of 179 countries on its corruption perceptions index in 2007, putting it between Indonesia and Nigeria and indicating that its ranking has fallen steadily since $2001 .{ }^{41}$

Putin sought to control the oligarchs who, independently or with the assistance of state officials, had succeeded in gaining control of the most valuable state assets that had been subject to privatization. Recognizing that past activities would not withstand scrutiny, the oligarchs were eager to reach an accommodation with the new president. ${ }^{42}$ Initially, Putin sought to make offers the oligarchs could not refuse, and most obliged. However, a few, notably Berezovsky, Vladimir Gusinsky, and Khodorkovsky, did not.

These individuals refused to stay outside of politics. Berezovsky's and Gusinsky's media empires jeopardized state control over the principal media outlets. Khodorkovsky recognized that unless there were legal protections for private property, the state could always take away whatever it wanted. Consequently, he contributed to political figures who opposed Putin and made no secret of his own political ambitions. Under Putin, the procuracy brought many publicized criminal cases against Khodorkovsky and other oligarchs, and it successfully convicted Khodorkovsky, who remains in a Siberian prison today, of fraud and tax evasion. ${ }^{43}$

On March 2, 2008, Dmitry Medvedev became president and appointed Putin as prime minister. Although some government officials were transferred to new positions and individuals who had not previously held state posts assumed them under Medvedev, Putin's staff remains largely intact under the Medvedev administration. Furthermore, United Russia made Putin party chair, ensuring him a leading role in the Duma's dominant political party and providing Putin yet another means to retain his influence, should he cease being prime minister in the future. ${ }^{44}$

Susan Rose Ackerman notes that anticorruption efforts cannot succeed unless there is "strong international action against money laundering." 45 Thus, unless the government is willing to rigorously combat economic crime in a uniform and systematic fashion, the individuals and organizations that play an active role in the conduct of money laundering 
will thrive. As a result, national bodies engaged in AML activities are not usually highly effective. Once money-laundering networks are established, they can serve any client. If particular networks are effectively closed, new ones will take their place-these networks are impossible to eradicate because knowledge and connections are transferable. Consequently, I conclude that the Russian AML efforts will remain ineffective because political factors and corruption undermine the vigor with which Russian individuals and institutions combat money laundering, and this situation is unlikely to change.

\section{Nationalizations or Political Elite Expropriations of State Assets}

Russian law enforcement has never convicted a single high-level government official or oligarch who is in favor with the Kremlin of a financial crime. As Andrei Illarionov, Putin's former economic adviser, writes:

[A] guiding principle of Russia's new economic [and legal] model is selectivity. . . Politically, the corporate ideology may seem unclear: it does not look communist, or liberal, or nationalistic, or imperial. Instead, it is an ideology of "nash-ism," or in English, "ours-ism," in which subsidies, credits and powers are handed out to those who are "nashy.". . The point of the new model is to redistribute resources to "our own." 46

The Russian government's unwillingness to investigate numerous public and private officials whose wealth could have come from dubious means suggests that it lacks the willingness or motivation to solve criminal cases that involve members of the ruling elite.

Aleksandr Anikin, the General Procuracy's head of the Anticorruption Administration, notes that during Soviet times there were "sensational" prosecutions of high-level government officials but that this has not occurred in contemporary Russia. Instead, the most prominent cases seem to be against regional officials who do not enjoy support within the Kremlin. ${ }^{47}$

Many of the largest Russian enterprises are in the natural resources sector and generate profits from foreign export. Money is likely being skimmed off and placed in foreign bank accounts through fraudulent means by those connected with the Russian entity. There is a large and growing literature on international economic crime that implicates Russian criminal groups in corrupt enterprises and money laundering inside and outside Russia. ${ }^{48}$ Lilia Shevtsova writes that most Russian flight capital ends up in the major financial centers of the West. ${ }^{49}$ If it is true that some government-owned entities in the natural resource sector do not operate lawfully, the procuracy is failing to investigate because of incompetence, willful blindness, corruption, or a combination of these factors.

\section{Who Does Forbes Think Are Russia's Billionaires?}

Forbes's annual list of billionaires for 2008 included eighty-seven Russian citizens, seven of whom apparently live abroad. ${ }^{50}$ According to Forbes, Russia has more billionaires than any other country except the United States. In 2008, Forbes identified thirty-three more Russian billionaires than in $2007^{51}$-nineteen more than in $2006 .{ }^{52}$ The worldwide price of energy and the appreciation of the ruble against the dollar partially explain this rise. ${ }^{53}$

Until 1997, there were no Russian billionaires on the list. ${ }^{54}$ For context, the 2008 Forbes report provides details on 1,062 billionaires, with a range from $\$ 1$ billion to $\$ 62$ billion in personal holdings. At the top of the Russian list is Russian aluminum magnate Oleg 
Deripaska, with more than $\$ 28$ billion; in 2007, Roman Abramovich had the highest net worth among Russians with $\$ 18.7$ billion (and $\$ 23.5$ billion in 2008's ranking). ${ }^{55}$ There is unquestionably a group of exceptionally wealthy individuals in Russia.

Luisa Kroll notes that the Russian billionaires in the 2007 list did not fit the typical categories of "inherited" or "self-made" wealth, ${ }^{56}$ although the report characterizes their fortunes as "self made." 57 Although Forbes identifies no federal governmental officials as billionaires, it does name several individuals who have served as legislators and local officials. According to the Russian newspaper Vedomosti, Russia's billionaires are the youngest from any major country, having an average age of forty-six, whereas the average global age is sixty-four. ${ }^{58}$ It is indeed possible that only more youthful individuals possessing greater market knowledge would excel in an economy undergoing rapid privatization-but there are other explanations as well. ${ }^{59}$ The Forbes data indicate that the majority of the Russian billionaires started in the natural resources sector and accumulated their wealth in a very short time-a significant feat given Russia's unstable economic conditions in the 1990s. In several cases, agreements to act as undisclosed agents for corrupt officials played a role. ${ }^{60}$

How reliable is the Forbes list? It was assembled largely from looking at publicly available information and from speaking with individuals who deal with Russian business matters. Consequently, it should not be a surprise that it does not include any fulltime government officials or individuals considered by law enforcement institutions to be members of organized crime groups. Persons falling within these categories might have incentives to protect their anonymity.

\section{Does Political Power in Russia Translate into Economic Power, or the Reverse?}

Although government officials are legally required to disclose their income, some officials likely abuse their state positions and misrepresent their assets. ${ }^{61}$ Russian Procurator General Yuri Chaika asserted that about 100,000 Russian government officials have been implicated in unlawful conduct, including failure to submit tax declarations or submission of false ones. In early 2008 , he said that these officials "had to put their affairs in order" or they would face legal consequences. ${ }^{62}$

Would it be correct to assume that, in a state in which private property rights are ensured through political connections, none of Russia's 100,000 government officials have allegedly engaged in unlawful conduct? Given the restrictions on the entrepreneurial activities of government officials, even if some were billionaires, they would not want this information disseminated.

Although Abramovich held the position of Chukotka governor from 2000-2006, few of the Russian billionaires identified by Forbes have held public office. ${ }^{63}$ However, many senior Russian officials also held (and some continue to hold) prominent positions in Russian commercial enterprises. Table 1 presents Marshall Goldman's identification of siloviki who publicly held prominent positions in government and the private sector at the same time.

According to Forbes, Russia's richest woman is Elena Baturina, who is married to Moscow Mayor Yuri Luzhkov. Although she allegedly made her fortune in Moscow real estate, her husband's influence most certainly played a role in her financial success. ${ }^{64}$

Whereas some individuals were able to use their political connections to obtain prominent positions in the private sector, according to Time, some people used their personal 
wealth to obtain positions, which they used subsequently to extract bribes or obtain other financial benefits. According to one unnamed source, a prospective regional governor must make illicit payments to political bagmen in Moscow to get Kremlin approval for the job. For wealthy regions, the prospective governor must raise $\$ 20$ million from corporate "sponsors," who will expect preferential treatment in return for their contributions. According to the article, "[t]he amount of money flowing to kingmakers in the Kremlin ... is staggering." 65

Stanislav Belkovsky, a Russian political analyst with close Kremlin ties, gave sensational interviews to Die Welt and the Guardian in November 2007, in which he stated that Putin is worth approximately $\$ 40$ billion, as the beneficial owner of 37 percent of Surgutneftegaz ( $\$ 18$ billion), 4.5 percent of Gazprom ( $\$ 13$ billion), and half of Gunvor ( $\$ 10$ billion), a Swiss-based oil trading company run by a former St. Petersburg KGB agent. ${ }^{66}$ If these allegations are true, this fortune would make him the richest person in Europe and one of the ten wealthiest people in the world. The allegations would also make him the most corrupt person in the world ${ }^{67}$ Although these claims cannot be verified, there is increasing evidence that some Russian government officials close to Putin have offshore holdings worth billions of dollars. ${ }^{68}$

In November 2007, the Wall Street Journal reported that Russian Minister of Telecommunications Leonid Reiman, formerly of the St. Petersburg KGB, owns billions of dollars in Russian telecommunications assets through sham corporations in the British Virgin Islands (BVI). In a letter from the BVI director of public prosecutions to the U.S. Department of Justice, the public prosecutor stated that there is "overwhelming evidence" that Reiman secretly owns a large share of Russia's telecommunications industry through IPOC International Growth Fund Ltd., a suspected BVI money-laundering vehicle. BVI prosecutors requested help from the U.S. Department of Justice because shell corporations are registered in Delaware, Kentucky, and other states. ${ }^{69} \mathrm{An}$ earlier Swiss arbitration panel found that Reiman held beneficial ownership worth billions of dollars in Russian telecommunications assets. ${ }^{70}$ IPOC cited in its defense that the Russian General Procuracy had cleared it of money laundering in 2006 and found no evidence that Reiman had abused his position. ${ }^{71}$

Is it possible that any billionaires' club could exist in Russia without official blessing? Given what we know about Russia, some (perhaps a majority) of its billionaires undoubtedly made their fortunes through corrupt means. It is striking that the General Procuracy has not publicly investigated or prosecuted any of the billionaires, indicating that although the procuracy is free to investigate and prosecute routine criminal matters, it is strictly controlled regarding investigations of criminal activity among the ruling elite. ${ }^{72}$

The procuracy primarily prosecutes crimes committed by those who have fallen out of political favor. ${ }^{73}$ According to Shevtsova, Putin's drive to reduce the power of regional officials started shortly after taking office. Outwardly, the cleanup of regional governments could resemble a return to legality because many of the governors Putin's people went after were corrupt or guilty of other serious misconduct. But the Kremlin's "cleanup policy" in the regions had nothing to do with the rule of law. Moscow was using the courts in the name of political expediency to support Kremlin loyalists and weaken independent politicians and the Kremlin's foes. The Kremlin even had a list of leaders to be discredited, details of timing and method and names of the courts responsible for 


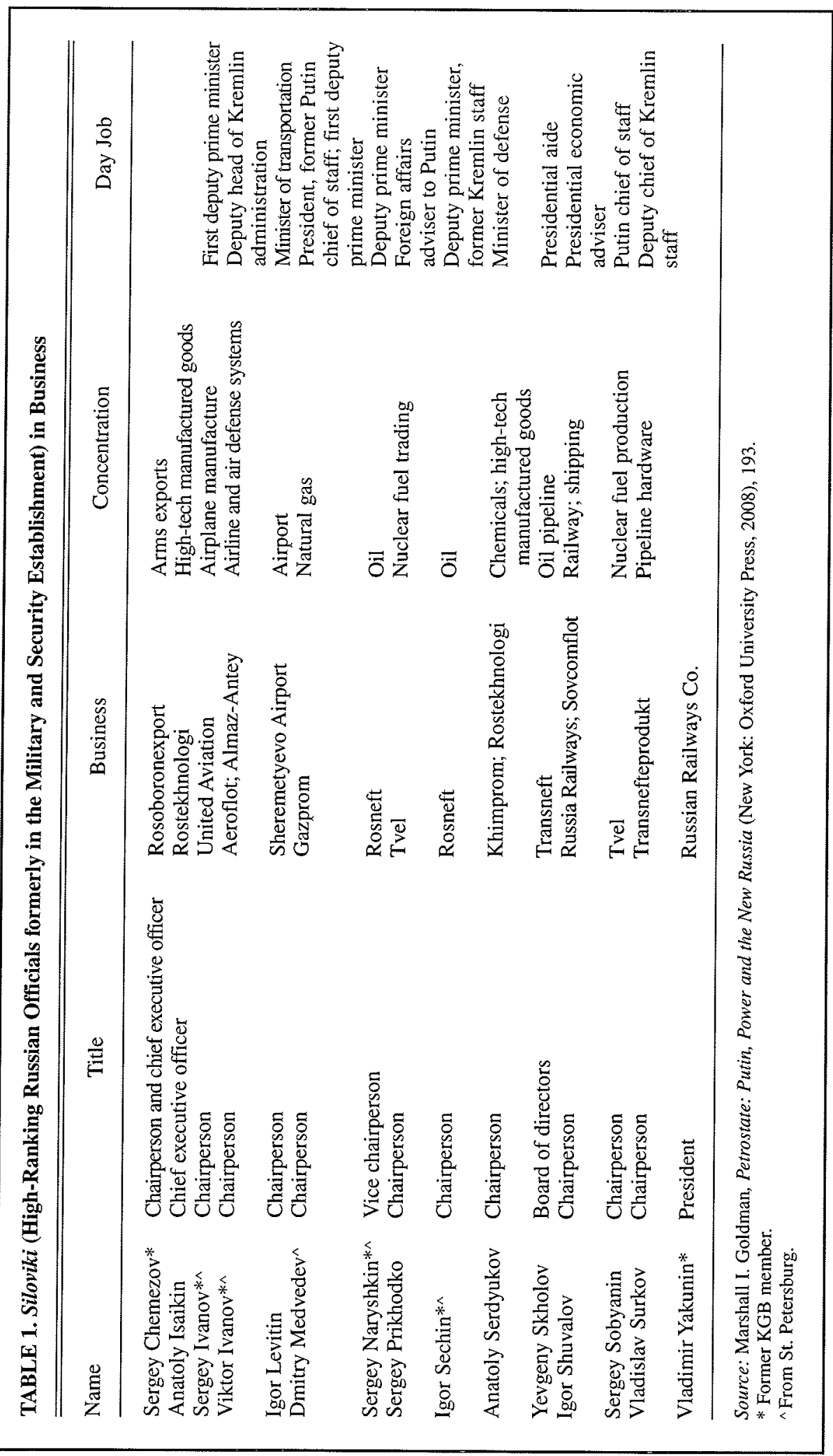


passing sentence on them. In some cases, the courts did clear away corrupt politicians. But in other cases they moved, under pressure from Moscow, against the political opponents of the center. The court system was turning into an appendage of the executive branch, as it had been in the Soviet era. ${ }^{74}$

Chaika recently said that the "war on [corruption] is one of our priorities."75 Aleksandr Bastrykin, chair of the Investigative Committee, stated that the procuracy opened more than 1,000 criminal cases in 2007 against Russian officials with special legal status (i.e., prosecutors, judges, and legislative deputies of various levels), many of which were related to corruption. ${ }^{76}$ Despite these proclamations, in the words of the Moscow News, "the fight against graft and corruption in Russia usually targets low-level bureaucrats. Investigation, let alone prosecution, of officials in the upper reaches of power are extremely rare."77 The procuracy usually accuses low- and mid-level officials, and the sums of money at stake are comparatively small. ${ }^{78}$

The following are some of the most prominent examples of threatened or actual expropriation, without resort to the courts and without fair compensation. ${ }^{79}$ It is difficult, if not impossible, to accurately estimate the value of the expropriated assets.

- TNK-BP: The Russian government essentially expropriated a large undeveloped Siberian Kovykta gas field owned by TNK-BP (owner of Russia Petroleum) to Gazprom after it was threatened with having its production license withdrawn in $2006{ }^{80}$ The Russian government subsequently created numerous obstacles to the proper functioning of the joint venture throughout 2008 , including refusing to grant visas to BP personnel. The matter has evolved into a shareholders' dispute between BP and the Russian shareholders. ${ }^{81}$

- Norilsk Nickel: Mikhail Prokhorov was forced to sell his 26 percent stake in Norilsk Nickel to Kremlin ally Mikhail Potanin. ${ }^{82}$

- Royal Dutch Shell PLC: The government forced the company to sell a portion of its rights to oil and natural gas in the Sakhalin II project to Gazprom and to make other major financial concessions. ${ }^{83}$

- RussNeft: The principal owner of Russia's seventh-largest oil company is likely to lose control of the company because of alleged tax violations amounting to approximately $\$ 800$ million. ${ }^{84}$

- Sibneft: Gazprom acquired Sibneft from Abramovich in $2005 .{ }^{85}$ Abramovich allegedly intimidated Berezovsky, then living in exile in London, into selling his shares in Sibneft, threatening that Gazprom would ultimately take over the company, which it did. ${ }^{86}$

- Tomskneft: Alleged embezzlement by an employee and tax evasion led to its auction, which the state-controlled Rosneft won. ${ }^{87}$

- Yukos: A sale was forced of Russia's most successful and transparent oil company, estimated to have been worth $\$ 100$ billion, for alleged tax violations; its owners and several employees were imprisoned on criminal charges. ${ }^{88}$

The Yukos expropriation is especially significant because the assets were so enormous. Former economic adviser Andrei Illarionov characterized the seizure and reselling of Yukos's assets to Rosneft as "the biggest scam of 2006." He said, "[T]his falls under the category of what people call the sale of stolen property." 89 These actions against Yukos undermined property rights, discouraged investment, and sparked capital flight. ${ }^{90}$

Based on conversations with people in the energy sector, Catherine Belton writes: 
The few remaining independent and foreign oil majors operating in Russia question how much further the state control drive will go. In a global energy environment of high prices and increasing clout by state-owned companies, "not one asset that belongs to a major foreign corporation in Russia is free from the risk of being swallowed by a state company," says Vladimir Milov, former deputy energy minister. In four years, foreign oil majors have gone from nearly landing a significant stake in Yukos-which could have given direct access to nearly a quarter of Russia's oil reserves-to being squeezed on all fronts. "The rules are clear if you want to be in the game," says Chris Weafer, head strategist at Alfa Bank. "The state has direct control and will selectively bring minority partners in." 91

First Deputy Prime Minister Sergey Ivanov has been candid in describing Russian state policy in the natural-resource sector. According to Ivanov, the state's share in the energy sector will "always be higher than 75 percent by definition" for national security reasons. Ivanov justifies state control of oil and natural gas by observing, "[T]hey are our resources and how to develop them and where to get funds from is our business." Thus, although foreign companies may participate as investors or contractors, he does not "think that in the foreseeable future we will allow any foreign company to own any major field." ${ }^{\prime 2}$ Ivanov did not clarify how the government would always maintain at least a 75 percent stake in the energy sector.

In November 2007, Oleg Shvartsman, head of Russian Finansgrupp, which reportedly managed approximately $\$ 3.2$ billion in assets for "the Party, the power block headed by Igor Ivanovich Sechin," gave a revealing interview about government expropriation methods. ${ }^{93} \mathrm{He}$ explained that one of the government's tasks is to increase the tax base in poorer regions, so that state salaries and pensions are paid on time. He said that to do this:

We don't take over companies, we minimize their market value using various instruments. Generally these are voluntary-compulsory instruments-market value, the mechanism of blocking growth, all sorts of administrative matters. . . Essentially we're carrying out a state task-everyone understands we have been instructed to do this. ... This is current state policy. ${ }^{94}$

Although the state's asset takeovers in the natural resource sector and the media are probably the best-known instances of the renationalization efforts in Russia, there are other examples, too. Some have occurred in sectors in which many other governments would be reluctant to employ private ownership, such as defense and telecommunications. In 2008, Russia adopted a law that restricted foreign ownership in certain sectors-not surprisingly, many of the same sectors in which renationalization occurred. ${ }^{95}$ Table 2 lists some of these renationalizations.

When the state reacquires control over such enterprises, sometimes the former owners are not adequately compensated, and other times the state overpays for the asset as a means of enriching its favorites in the process. (Sometimes kickbacks are involved or various middlemen whose purposes are not always clear-frequently the latter are foreign business consultants who are based offshore, providing another way to launder money.) Furthermore, it is not possible to determine whether kickbacks to government officials were involved.

Most Russian state enterprises operate in an opaque manner. This is the case for much of the Russian government. As the Russian government acquires more industrial assets and natural resources, it would be interesting to study how these enterprises' revenues 


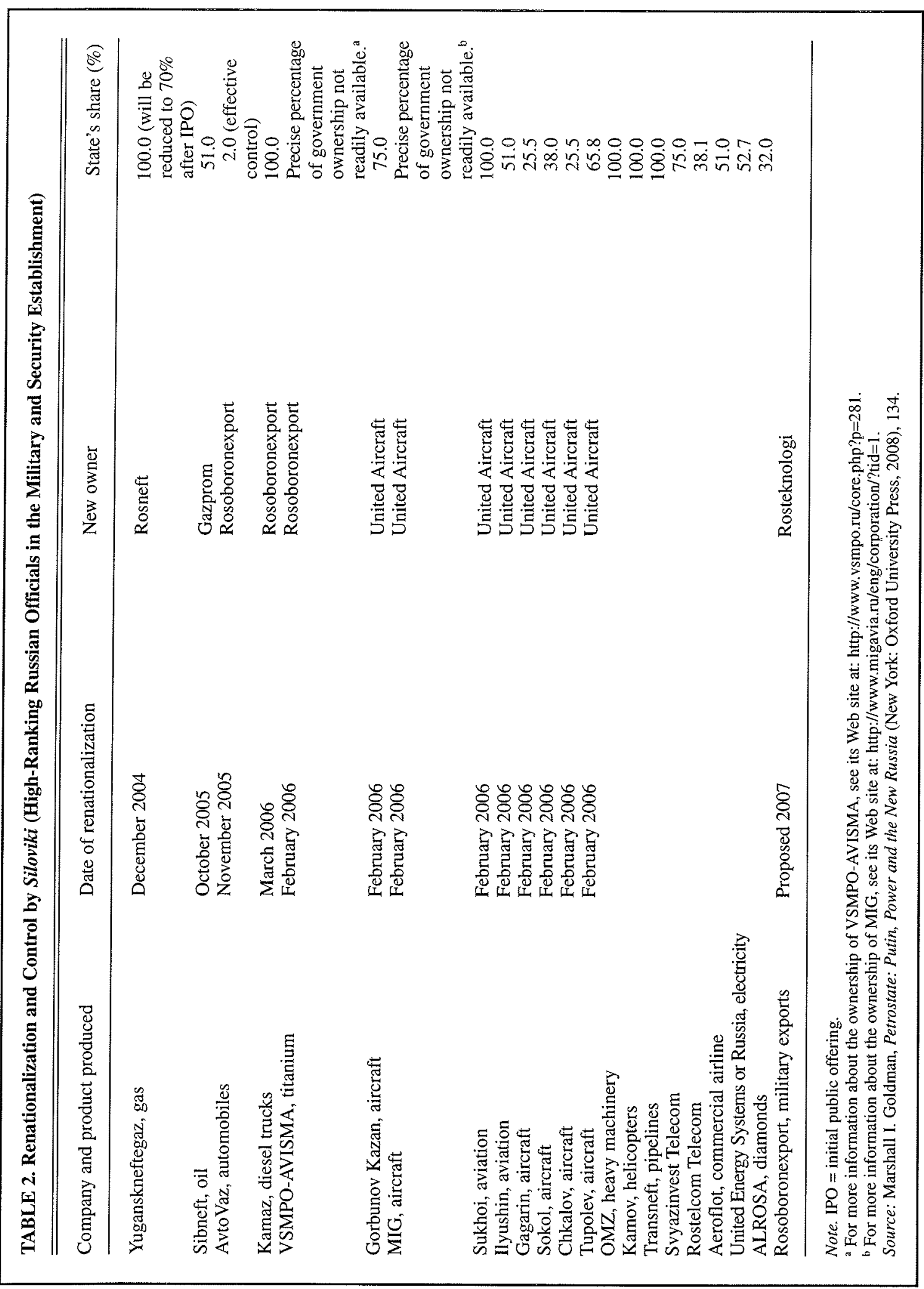


are used, but it seems unlikely that such information will become widely available in the near future.

\section{International Evaluations of Russian Anti-Money-Laundering Systems}

The Russian constitution acknowledges universally recognized international legal norms and treaties as binding. Article 15(4) states that in the event of a conflict between domestic law and an international treaty to which Russia is party, the international treaty applies. ${ }^{96}$ Russia is a member of the Council of Europe and various agreements commit it to taking actions to combat money laundering.

\section{The Financial Action Task Force's Assessment of Russia's Anti-Money-Laundering System}

Created in 1989 primarily to combat the financing of the international narcotic trade, the Financial Action Task Force (FATF) is the principal international membership organization dedicated to combating money laundering. ${ }^{97}$ It has thirty-four members (thirty-two countries and two regional organizations) and twenty-seven associate members. Russia became an FATF member in 2003. ${ }^{98}$

In theory, a country must meet certain criteria to become an FATF member. ${ }^{99}$ It is unlikely that any country's political leadership will publicly acknowledge that they have no desire to reduce money laundering. FATF membership criteria, however, are vague enough to permit any economically significant country to join. If a country has made money laundering a criminal offense and has established a financial intelligence unit, it is doubtful that it would be excluded irrespective of its actions.

Furthermore, governments are not unitary actors. Thus, it is conceivable that one government body or group of politicians within that body may have views consistent with FATF objectives, whereas another does not. Allowing such a country to join may allow existing FATF members to gain insight into money-laundering threats originating in that country and providing moral and other support to those institutions or individuals favoring stricter money-laundering policies.

The FATF does not have any independent law enforcement powers. It is an entity with a mission rather than a club. Consequently, to become an FATF member, a state must possess the building blocks for creating effective AML policies (e.g., laws and government agencies). FATF membership does not denote that a country has an effective AML system in place.

The FATF"s purpose is to facilitate "the development and promotion of national and international policies to combat money laundering and terrorist financing." 100 It issues legislative and operational recommendations, functions as a clearinghouse for AML methodologies, and provides assessments of its members' operations.

FATF assessments serve two important functions. First, countries that are the subject of an evaluation report may be motivated to take steps to correct the shortcomings that the team conducting the assessment identifies. Second, foreign government officials may have their own AML personnel pay special attention to weaknesses in other countries' moneylaundering activities brought to light as a result of the assessment.

In 2007, FATF sent an assessment team to Russia to evaluate its AML program. The FATF team prepared a very comprehensive report. While seeking to highlight positive developments in Russian AML operations, the team also identified the Russian system's numerous shortcomings. A few examples of the team's observations are: 
- The money laundering offense includes any property and monetary funds. The launderer does not need to be convicted of a predicate offense to prove that property constitutes the proceeds of crimes. For money laundering, all crimes are predicate offenses with the exception of six financial crimes. ${ }^{101}$ The exclusion of these crimes makes the criminalization of money laundering less effective overall. Nineteen of the twenty predicate offenses for money laundering that FATF recommendations require be covered by the money laundering offense are covered. However, insider trading and stock manipulation are not distinct criminal offenses, although elements can be found in some other laws.

- The money laundering offenses are being increasingly prosecuted; the number of money laundering investigations has jumped from 618 in 2003 to 7,957 in 2006. The number of money-laundering cases being brought to court has increased from 465 in 2003 to 6,880 in 2006, and the overall number of convictions has increased from 14 in 2003 to 532 in 2006 . However, considering the level of organized crime and corruption that the Russian authorities acknowledge, authorities should make more money laundering charges in the future. ${ }^{102}$

- Measures against politically exposed persons (PEPs)—which are essentially government officials-are very recent and their effectiveness was not assessable. ${ }^{103}$ However, the legal framework should be completed as soon as possible. Although FATF standards do not strictly require it, Russia should consider prosecuting domestic PEPs in the fight against corruption. This is possible only if they do not enjoy immunity; Russian legislation provides mechanisms to eliminate immunity for legislators and certain other officials (including the president). In relation to correspondent banking, all of the relevant criteria confirming that these banks are licensed and observing AML/Combating the Financing of Terrorism (CFT) requirements should be implemented, especially the need to understand the nature of the respondent bank's business and to determine whether the respondent bank's AML/CFT system is effective. The requirement to document the respective AML/CFT responsibilities of banks should also be covered. The team did not find any practical problems with financial secrecy provisions.

- The evaluators concluded that the supervision carried out by the RCB is generally detailed, in-depth, and effective. RosFinMonitoring and the Federal Insurance Supervision Service should inspect securities market participants more frequently, however. On average, each participant is inspected only once every nine to ten years, and each insurance company is inspected only once every five to six years. Leasing companies are inspected only once every eight to thirteen years. RosFinMonitoring's and the Federal Insurance Supervision Service's reports were determined to be insufficiently detailed. ${ }^{104}$

- The requirements for lawyers, notaries, and accountants were found to be incomplete or not implemented effectively. The designated nonfinancial businesses and professions that the evaluation team met with implemented the requirements in different manners, which were sometimes not in line with the law. The team also raised some specific concerns about the effectiveness of the regime for casinos and the real estate sector. ${ }^{105}$

According to FATF's findings, Russian government officials were not of one opinion. RosFinMonitoring Head Yuri Chikhalin described Russia as having received a high AML rating, comparable to Canada, Italy, and Sweden. ${ }^{106}$ In contrast, Sergey Osipov, RosFinMonitoring's 
deputy head, was more candid about FATF's evaluation of Russia's AML efforts. In his remarks at a news conference he noted that Russia was one of the five worst performing counties with respect to money laundering prevention. He focused on several of FATF's criticisms: the quality of the Russian authorities' knowledge over enterprises' overseas subsidiaries and branches, payment systems, and how companies move funds abroad. ${ }^{107}$

\section{The West's Complicity in Russian Money Laundering}

The large amounts of money being laundered out of Russia could not occur without the complicity of Western accountants, bankers, and lawyers. ${ }^{108}$ Sometimes the professionals are offering services without providing adequate due diligence before agreeing to take on new clients. Working for Russian clients who illicitly acquired their property can be so lucrative that many are persuaded to assist them in circumventing the relevant AML systems and ensuring that law enforcement does not see any red flags that might indicate illegal activities. Furthermore, it is not illegal for Russian companies and individuals to pay bribes to obtain or retain business (this behavior is illegal for Organization for Economic Co-operation and Development member states), and many countries' AML regimes do not consider most offenses when committed abroad as predicate offenses for money-laundering purposes. ${ }^{109}$

Many former KGB operatives who knew how to deal with hard currency abroad frequently found their skills in demand by Russians businesses and individuals to assist in money laundering. The final step of money laundering is placing funds into the economy so that they can be used in the future for any purpose, at which point their illicit origin is generally not discernible.

The vast amount of funds being sent out of Russia do not end up in offshore tax havens, such as Bermuda, the Cayman Islands, or Nauru. Such locations are used primarily for the previously discussed technique of layering (although there might be some investment in these locales). Some of the money finds its way back to Russia (or other nearby countries) through companies in Austria, Cyprus, Ireland, Jersey, or the United States as "foreign investment." However, the vast majority remains in the more developed economies of Canada, EU member states, or the United States, or it is invested abroad in foreign companies, such as Nigerian energy companies.

Thus, the most developed countries are the greatest beneficiaries of money laundering, and their governments are generally not enthusiastic about enforcing their own laws, even if they have the necessary AML systems, such as personnel, laws, equipment, and so on. ${ }^{110}$ This may occur not merely because individual "legitimate" businesses and individuals are making money, but also because of a lack of political will by governments that depend on Russian energy and raw materials or states that regard Russia as an import market for their exports. ${ }^{11}$

Russians could not be successful in their money laundering without the assistance of Western banks. According to Gerald Hersztera, a spokesman for the Austrian Interior Ministry, Reiffaissen Bank may have been involved in a multi-million-dollar money-laundering scheme that may have some ties to the murder of the RCB's first deputy-chairman, Andrei A. Kozlov. ${ }^{112}$ The murder case has not been solved.

According to a U.S. General Accounting Office (GAO) study conducted at the request of U.S. Senator Carl Levin, billions of illicit funds of Russian origin found their way into the U.S. economy by $2000 .{ }^{113}$ The GAO study was limited in scope. It focused on the activities of the Delaware-registered agent Euro-American Corporation Services, Inc., and 
a related entity, International Business Creation (IBC), both of which created corporations and opened accounts for Russian brokers. ${ }^{114}$ According to the GAO report:

Euro-American formed corporations pursuant to the General Corporation Law of Delaware. The corporations were granted corporation status by the state after Euro-American - as the registered agent-prepared, signed and filed a certificate of incorporation containing very limited information. For example, Delaware law, as in some other states, has no requirement that the certificate of incorporation contain information about the principals, the principal place of business, or the specific business activity of the corporation.

We also determined that Euro-American had formed three Delaware corporations identified by the Subcommittee, as well as approximately 2,000 others, for Russian brokers. From 1991 through January 2000 , more than $\$ 1.4$ billion in wire transfer transactions was deposited in 236 accounts opened at 2 U.S. banks: Citibank (136 accounts) and Commercial Bank (100 accounts). [International Business Creatons]/Euro-American established those accounts for corporations that it had created. Of the $\$ 1.4$ billion, more than $\$ 800$ million was wired from foreign countries into IBC/Euro-American accounts at Citibank. Over 70 percent of the Citibank deposits for these accounts was wire-transferred to accounts in foreign countries. Of the remaining $\$ 600$ million deposited in Commercial Bank, over 50 percent was similarly transferred into the U.S. banking system from abroad. In addition, most of the $\$ 600$ million was transferred out of the U.S. banking system. These banking activities raise questions about whether the U.S. banks were used to launder money. ${ }^{115}$

Although most companies are taking added steps to reduce their susceptibility to money laundering, money launderers are able to adapt to changes in regulator regimes. First, each country's rules in these areas are readily available-making them easier to exploit. Second, money launderers are becoming increasingly sophisticated as they increasingly use shell corporations (thinly capitalized entities placed in a corporate structure to limit liability) and captured businesses (a business controlled by another business entity) that are actually engaged in commercial activity. Often the managers of such businesses and professionals, either retained on a one-time basis or as employees, are unaware of their employer's identity as a result of complex structuring involving holding companies located in other jurisdictions.

Money launderers are increasingly able to operate without third parties. Initially, launderers are often reliant on the advice of professionals, such as accountants, bankers, and lawyers, all of whom are obliged, to varying degrees, to communicate any suspicions they may have of their client being involved in money laundering. However, another complexity that cannot be overlooked is that the purpose of money laundering is to move value, which need not be money. Rather, it can take the form of (legal or illegal) commodities, such as securities, real estate, and so on.

Often the criminals involved know of individuals employed by private entities (e.g., banks) or government employees who are willing to cooperate in the scheme as long as they are paid a sufficient amount. ${ }^{116}$ There are few law enforcement or regulatory organizations that do not employ individuals who are willing to facilitate illegal actions for payment significantly greater than their salaries.

Unfortunately, the Russian people are the greatest victims of money laundering because the state is losing billions of rubles in taxes and capital that could be spent on education, health, housing, and other needs. According to an investigation with the head of the MVD's investigative committee, Major General Igor Tsokolov: 
The damage done to Russia's economy by the illegal conversion of funds into cash and by money-laundering runs into hundreds of billions of rubles. ... [S] $]$ ums [are] between ... 3 billion [rubles] and . . 100 billion [rubles, a]nd law-enforcement agencies are managing to find and recover only a small proportion-a hundred million or two, as a rule. The rest of the money has been shipped abroad by then. By whom and where is unclear. Only a small proportion of the cases that are investigated come to court and lead to successful prosecutions of specific individuals. But one major trial is due to start in the very near future: Boris Sokalskiy, former chair of the NEP-Bank board, is under indictment for converting ... 62 billion [rubles] into cash. ${ }^{117}$

One might expect that answering the questions "By whom and where?" would be a major objective of the investigative committee. When a traditional criminal group or individuals not enjoying the leadership's favor commit the offenses, the authorities usually seek to solve the matter. However, when those involved in or profiting from moneylaundering funds are members of the Russian political and economic elite, an examination of recent investigations and prosecutions suggests that little to no effort is made by Russian AML personnel. One prominent example of the Russian authorities protecting a friend of Putin is previously discussed the Reiman affair.

\section{Selectivity in Pursuing Money Launderers}

AML legislation increasingly contains provisions concerning PEPs. In most cases, such PEPs are present or former government officials or individuals acting as their agents. Governments are willing to treat money-laundering activities by PEPs solely as a law enforcement matter only when PEPs are former officials who lack friends serving in their country's current government. In many cases, however, PEPs either still hold government positions or have connections to individuals who do. Hence, the offense of money laundering often receives secondary consideration.

Furthermore, PEPs (and private individuals) may possess enough wealth to effectively retaliate against a government that seeks to prosecute them. In theory, financial institutions are supposed to closely monitor PEPs. Often, this occurs only during the initial client due diligence (i.e., an investigation of the entity, its managers, directors, and owners), which is often perfunctory rather than diligent. In table 1 , for example, most of the Russian siloviki identified have political ties or financial assets that provide them with a measure of immunity.

\section{Yet Another Anticorruption Campaign?}

In May 2008, Medvedev announced his intention to formulate a systematic response to combat corruption to address the systemic problem of money laundering. The Medvedev administration knew the basic contours of its program from the outset. He organized an Anti-Corruption Council, making himself the chairperson. He initially found one idea appealing - giving the judiciary a major role in the implementation of the program. Not surprisingly, this was not well received by Chaika and the General Procuracy or Bastrykin and the Investigative Committee, both of whom hoped that their organizations would be assigned the leading role in the effort. ${ }^{118}$ What followed was a combination struggle of bureaucracies, personalities, and power politics. ${ }^{119}$

Naryshkin presented the initial draft program to Medvedev and the Investigative Committee-the body tasked with investigating major corruption cases-presented its own concept. According to Naryshkin: 
The plan consists of four parts. Part one deals with legislation. A bill on prevention of corruption is to be submitted to the Duma by October 1, 2008. The second part deals with advancement of anti-corruption governance by the state (probably tests for state officials and struggle for transparency of their families' income). Measures to up professionalism of lawyers comprise the third part, implementation of the plan itself the fourth. ${ }^{120}$

The Law on Counteracting Corruption ${ }^{121}$ is an amalgam of already existing but unimplemented rules and new provisions, many of which are likely to prove difficult to implement. Not surprisingly, many observers were cynical about the entire effort, seeing it as primarily a battle between competing bureaucracies and efforts to provide the illusion that something was being done to address a widespread problem. ${ }^{122}$

The law should be understood as providing a framework that envisions a great deal of further legislation and rule writing. Ethics offices will need to be established. Government workers will need to be trained. Written guidance and real-time tele'[I]n Russia it is always the case some people are found at the lower or middle level, while no one at the top is.... That is why I think this is just a PR campaign and nothing more'. phone or computer hotlines must be established. Corruption can only be addressed with a significant commitment of resources and support at the highest levels. Completely eradicating corruption is unrealistic; a far more reasonable goal is reducing it to more acceptable levels.

Proponents of the new law say that, for the first time in Russia, legislation defines "corruption." For example, Russia is a party to two international agreements concerning corruption, but neither the Council of Europe's Criminal Law Convention on Corruption $^{123}$ nor the United Nations Convention against Corruption ${ }^{124}$ defines the corruption. The former document does discuss specific offenses, making this less of an issue than in the latter document because the United Nations Convention against Corruption is less likely to serve as a legal basis for concrete actions in the absence of other bilateral agreements.

Despite this flurry of activity, there is considerable skepticism about these latest anticorruption proposals. One of the members of the State Duma Commission on Legislative Support for Countering Corruption, Gennadi Gudkov, expressed the belief that even if Medvedev seeks to establish new anticorruption norms, given the government opposition to improvements in this area and the lack of political will to vigorously implement them, the new anticorruption measures are doomed to failure. ${ }^{125}$

Kirill Kabanov, director of the National Anti-Corruption Committee, indicates that a true measure of a war on corruption would be a case against someone close to those in power. He remarked, "[I]n Russia it is always the case some people are found at the lower or middle level, while no one at the top is. . . That is why I think this is just a PR campaign and nothing more."126

Georgy Satarov, a former aide to Boris Yeltsin and the director of the think tank INDEM, calls the rise in corruption from 2001 to 2005 "catastrophic": 
The growth of the average size of a bribe during the period can be characterized as follows, taking into consideration inflation, GDP growth, the turnover of firms, and other economic dynamics. In 2001, an average-sized bribe could buy 30 square meters of habitation according to the average Russian prices on the primary [real estate] market (a piece of a single-room apartment). In 2005, an average sized bribe could buy 209 square meters [a few] apartments. Is it any surprise that youth now want to be officials, and not businessmen? ${ }^{127}$

Evidence abounds that the fight against corruption in the legal system is illusory. According to the chairman of the Supreme Court, 69 judges, including chairs of specific courts, were suspended on corruption charges and 224 judges received disciplinary warnings in 2003. Nonetheless, then-Procurator General Vladimir Ustinov indicated that only 4 were prosecuted. ${ }^{128}$ The "war on corruption" is clearly the right bandwagon to be on in Russia today. In Medvedev's first major campaign speech, he decried Russia's "legal nihilism" and ubiquitous corruption. ${ }^{129}$ In February 2008, Prime Minister Viktor Zubkov condemned corruption at a meeting of procuracy officials, saying, "[I]t takes our Western colleagues just six minutes to let pass one automobile, and we spend six hours on this." ${ }^{30}$ He noted that this is because of "bribery, corruption-impudent and open."131

After these sections, new law identifies new legislation that is needed and a list of existing legislation that needs to be amended. The plan reads like an amalgamation of the extensive literature about corruption in general and in Russia in particular. Some of the provisions of the plan are specific, but many are general, which will leave people in a quandary concerning what is to be done.

It is possible that the plan is too ambitious for it to achieve its objectives. Realistically, given the likely opposition to it and the organizational problems that would exist in implementing it, it seems as if it is oriented primarily to address those forms of corruption that are politically safe to confront.

The plan is a document without specific context, and it is clearly not aimed at specific individuals; nor does it seek to rewrite Russia's recent history. Arguably, if the strict application of the law were applied, some very prominent individuals would be investigated. It is highly unlikely that the new Russian president will place himself on a collision course with his mentor. Medvedev's decision to retain Bastrykin as chief of the investigative committee indicates that Medvedev does not intend to use law as a vehicle to undo political arrangements that are acceptable to the country's leading political figures.

The scope of corruption is so great that investigative committee personnel could be working constantly without threatening the country's political elite. According to Bastrykin, Russian law enforcement authorities initiated over 1,000 bribery investigations in the first quarter of 2008 , which represents a rate of twice the number of corruption investigations undertaken for $2007 .{ }^{132}$ Of course, investigations need not result in criminal convictions, when convictions occur the penalties might be light, and prosecution of individuals involved in a particular case may be selective.

\section{Conclusion}

Most criminal investigators specializing in money laundering will say that to solve a financial crime, one needs to follow the money. Ultimately, the money will be placed back in the legitimate economy. Combating money laundering requires skilled personnel, material resources, and patience. 
Most corruption having major economic stakes involves control over assets that produce considerable revenue. If the funds end up abroad and their origins were deemed to be illicit, there exists the possibility that foreign law enforcement will treat such funds as the illegal proceeds of a criminal operation, depending on the provisions of the relevant legislation.

A critical element in combating money laundering is determining the true beneficiary. This is often disguised through the use of family members, friends, shills (straw men), opaque shell companies, and trusts. Georgy Bovt has identified numerous shortcomings in the recent legislation framework with respect to combating corruption in general. One provision would seem to make money laundering in Russia easier. Bovt notes that the legislation for "the first time ever" requires all state workers

to declare all their property relations, as well as real estate and other property that belongs to their wives and underage children. However, for some reason, the law omits adult children who are often employed by businesses affiliated with the parents' governmental offices. So far, a very limited range of offices is subjected to the declaration process: mostly ministers and state machine employees of the same status. It will not be possible to significantly extend the list. . . The property declaration is supposed to be submitted to the head of a specific agency, who is not obligated to send it on to any competent authorities. Thus, it is up to the personal discretion of the agency head whether to appeal to the law enforcement authorities. But is there a top administrator who would be interested in "airing his dirty linen in public?"133

Bovt remains skeptical in light of recent experience, observing that "it is a well-known fact that the higher the position of the corrupted officer, the harder it is to catch him: today's corrupt high-ranking officers use the most elaborate schemes and off-shore accounts." 134 Vladimir Ryzhkov makes similarly cynical predictions. He envisions that if the law is implemented it will force corrupt officials to "start hiding their property and concealing their income more carefully." 135 He emphasizes in particular the role money laundering is likely to play in this process. After outlining various ways to circumvent restrictions placed on government officials, he notes, "[E]ven greater importance will be attached to offshore accounts, trusts, and other ways of taking money abroad where it is much more difficult to find and confiscate it."' 136

Bovt's and Ryzhkov's comments could describe state officials in many countries, but what is unusual about Russia, in contrast to a country like Nigeria, is the sophistication with which corrupt officials dispose of money from illicit sources. ${ }^{137}$ It remains to be seen whether these provisions are revised to make money laundering more difficult or if the loophole is permitted to remain. As is the case with all legislation, the written law may seem adequate, but it may not be properly implemented, given the government's lack of will or legislators' refusal to approve sufficient personnel and material resources to properly implement it.

It is unrealistic to think that governments can successfully combat money laundering without the effective coordination of international law enforcement bodies and private financial institutions. Ackerman perceptively concludes:

Fundamental change requires commitment from the top of government and a willingness to follow through as the anti-corruption effort unfolds. Serious reform can be carried out with any existing structure of government. Governments that make it very difficult for independent voices to be raised in criticism, however, will have an especially difficult time establishing a commitment to honest and transparent government. Such governments may be able to move quickly in the short run but pose the risk that their policies will be reversed in the future. Anticorruption campaigns can be used to undermine political opponents and discipline 
troublesome groups. Reformers should resist those who would use an anticorruption crusade to limit political opposition. Nominal reform efforts that become a vendetta against political opponents will lose credibility. In a highly politicized atmosphere, individualized prosecutions will not produce real reform. Only structural changes in the underlying corrupt incentives built into the operation of government can accomplish credible change. ${ }^{138}$

It seems likely that, in the near term, Russia will follow Ackerman's general observations about the relationship between corruption and government. Successfully laundered money represents a good measure of the nature of a particular ruling elite and the willingness of state officials to carry out the tasks assigned to them by law without favoritism. In addition, it is currently unrealistic to expect other countries to pursue such a policy where the Russian government opposes such actions. In light of the international financial crisis and its impact on certain members of the Russian political elite and their favorites, it is impossible to predict what the future holds for Russia's anti-money-laundering policy. It may become a vehicle for certain wealthy individuals to use against their competitors. It may also take on significant political consequences for the direction of domestic Russian politics.

\section{NOTES}

1. For more on RosFinMonitoring, see RosFinMonitoring, "Federal Financing Monitoring Service," RosFinMonitoring, http://www.fedsfm.ru/eng/ (accessed October 5, 2008).

2. United Nations Office on Drugs and Crime, "Money Laundering," UNODC - United Nations Office on Drugs and Crime, http://www.unodc.un.or.th/money_laundering/ (accessed October 10, 2008). For a discussion of the different stages of money laundering, see Peter Reuter and Edwin M. Truman, Chasing Dirty Money: The Fight against Money Laundering (Washington, DC: Institute for International Economics, 2004).

3. Most countries' financial intelligence units are members of the "Egmont Group," which was formed in 1995 and is an "informal international gathering of financial intelligence units," including RosFinMonitoring. "The Egmont Group," Egmont Group, http://www.egmontgroup.org/ (accessed October 10, 2008).

4. Law on Hard Currency Regulation and Control, Law of the Russian Federation (as amended), No. 3615-1, October 9, 1992. Originally, this law retained many features of Soviet currency regulation, particularly in the areas of the movement of currency values (substitutes for money like stocks, bonds, and promissory notes) across international lines, the opening of foreign bank accounts, the acquisition of foreign currency, and the mandatory sale of hard currency earned to the state. Over time, this law has been frequently amended to reflect many modern banking practices.

5. Ethan S. Burger and Louise Shelley, "Russia Finally Adopts a Law to Combat Money Laundering," Russia/Central Europe Executive Guide, October 31, $2001,9$.

6. See "The Criminal Code of the Russian Federation, no. 63-FZ", June 13, 1996, art. 1, 2, http:// www.legislationline.org/download/action/download/id/1697/file/0cc1 acff8241216090943e97d5b 4.htm/preview (accessed November 10, 2008).

7. For example, in 1999, Russia hosted a G-8 Conference in St. Petersburg at which it agreed to follow the recommendations of the Financial Action Task Force on Money Laundering (FATF) - the leading organization dedicated to combating organized crime and money laundering. "Ministerial Conference of the G-8 Countries on Combating Transnational Organized Crime (Moscow, October 19-20,1999):Communique,"U.S.Department of Justice, http://www.usdoj.gov/criminal/cybercrime/ g82004/99MoscowCommunique.pdf (accessed February 3, 2009), especially no. 24-42. Russia also became a party to the United Nations Convention against Transnational Organized Crime in New York in November 2000. United Nations Office on Drugs and Crime, "U.N. Convention against Organized Crime," UNODC-United Nations Office on Drugs and Crime, http://www .unodc.org/unodc/en/treaties/CTOC/countrylist.html (accessed October 20, 2008). Russia also has AML obligations arising from its membership in the Council for Europe. Council of Europe, "MOLI-RU 2: Project against Money Laundering and Terrorist Financing in the Russian Federa- 
tion," Action against Economic Crime, http://www.coe.int/t/dg1/legalcooperation/economiccrime/ moneylaundering/Projects/MOL1\%20RU-2/moliru2_en.asp (accessed November 10, 2008).

8. Money laundering can be understood as "the conversion of criminal income into assets that cannot be traced back to the underlying crime." Reuter and Truman, Chasing Dirty Money, 1.

9. "Russian Govt Wants Big Cuts in Banks--Sources," Prime-Tass, October 1, 2008. The Financial Times quotes an anonymous Western economist as saying: "By summer, Russia is going to be in very serious trouble." Catherine Belton and Stefan Wagstyl, "Battle Erupts over Budget Crisis," Financial Times, February 6, 2009.

10. Ibid.

11. Ibid. It is worth noting that RCB chair Sergey Ignatiev is also chairperson of Sberbank.

12. Ibid.

13. "Central Bank Goes Gangbusters against Third of All Bank Licenses," SKRIN Market \& Corporate News, September 9, 2008.

14. "Russian Central Bank Revokes Licenses from Two Banks," Prime-Tass, July 3, 2008.

15. On Approval of Regulations of the Federal Financial Monitoring Service, Government of the Russian Federation, Ordinance no. 307, June 23, 2004 (most recently amended October 27, 2007), http://www.fedsfm.ru/eng/files/ord307.doc (accessed February 3, 2009), 8. Formerly, RosFinMonitoring was within the Russian Ministry of Finance and, as a consequence, its head reported to Russian minister of finance Alexei Kudrin. "Putin Revises Fiscal Monitoring Service, Vows to Fight Corruption," RIA Novosti, September 29, 2007, http://en.rian.ru/russia/20070925/8076.html (accessed October 3, 2008).

16. Russian criminal law has two separate offenses that relate to money laundering. According to Alexandra Orlova, Article 174 of the Criminal Code of the Russian Federation "deals with thirdparty laundering, i.e., the laundering of criminal proceeds by persons not involved in the commission of the predicate offence that generated those proceeds[, whereas] Article 174.1 addresses the case of self-laundering, i.e., where the perpetrator of the predicate [offense] launders the criminal proceeds from that [offense him/herself]." Orlova, "Russia's Anti-Money Laundering Regime: Law Enforcement Tool or Instrument of Domestic Control?" Journal of Money Laundering Control 11, no. 3 (2008): 9-10.

It is especially significant that neither article of the law gives rise to money-laundering charges. More specifically, offenses defined by art. 193 (failure to return the means in foreign currency from abroad), 194 (evasion of custom payments), 198 (evasion of payment of taxes by a citizen), 199 (evasion of payment of taxes by organizations), 199.1 (failure to carry out the duties of a tax agent), and 199.2 (concealment of monetary means or property of an organization or an individual entrepreneur that is subject to taxation and/or collection) are excluded from the scope of predicate offenses. Hence, the above-mentioned offenses could only give rise to money-laundering charges if they also involved the commission of other criminal offenses (e.g., fraud, forgery of official documents, etc.). Many authors criticized the exclusion of art. 193, 194, 198, and 199 offenses because the commission of these revenue offenses generates large profits. Ibid., 10-11.

17. "Russian Police Report 2,000 Money Laundering Crimes in 2008," Itar-Tass, May 18, 2008.

18. Ibid.

19. Tatiana Aleshkina, "Anti-Money Laundering Efforts Become Personal," Kommersant, August 11, 2008, 9-11.

20. In April 2008, the Russian Association of Banks organized a conference called "Cooperation by Self-Governing Organizations and Supervisory Bodies in Resistance to the Laundering of Criminal Income and the Financing of Terrorism." As could be expected, the Association of Bankers, while noting the importance of combating money laundering, spoke out against burdensome reporting requirements, disruptive bank inspections, and the RCB's promulgation of mandatory AML requirements for banks. The banks prefer that the RCB only issue recommendations and that they be given the authority to refuse to open bank accounts for persons or entities that they view with suspicion. "Banks' Association to Step Up the Struggle with Money Laundering," Itar-Tass, April 29, 2008.

21. Aleshkina, "Anti-Money Laundering Efforts Become Personal."

22. Estimates of capital flight exceed $\$ 20$ billion. "Moscow Forced to Shore Up Ruble," SKRIN Market \& Corporate News, September 5, 2008. 
23. "Risks Rise as Route Ahead Is Unclear," Financial Times, October 1, 2008, 1; Catherine Belton, "Investors Are Adopting a Wait and See Approach after Georgia and the Credit Crunch," Financial Times, October 1, 2008; "Moscow to Lend \$50bn to Indebted Business," Financial Times, September 30, 2008; Sundeep Tucker and Catherine Belton, "Russian Banks Wary of a Foreign Withdrawal," Financial Times, September 29, 2008, 11; "LEX Column Russian Banks," Financial Times, September 26, 2008, 16; and Catherine Belton, "Retreat from Moscow; Investors Admit Defeat as Global Fears Stoke a Russian Crisis," Financial Times, September 18, $2008,13$.

24. Charles Clover, "Moscow Widens Emergency Funding," Financial Times, September 22, 2008,8 .

25. Charles Clover, "Russia's VEB to Buy Ailing Svyaz-Bank," Financial Times, September 24, 2008, 30 .

26. "CB Slashes Reserve Requirements for Banks as of September 18," Russia \& CIS Business \& Investment Weekly, September 19, 2008.

27. Natalia Starostina, "Bankers Persuaded the [RCB]," RCB Daily, October 1, 2008, 9; and Analytical Information Agency for the Russian Stock Market, "[RCB] Will Not Punish Offending Banks," Vremya Novestei, October 1, 2008, 9.

28. Starostina, "Bankers Persuaded the [RCB]," 9; and Analytical Information Agency for the Russian Stock Market, "[RCB] Will Not Punish Offending Banks," 9.

29. "CBR Alerts Banks to Monitor Some Intl Corp Money Transfers," Prime Tass, September $10,2008$.

30. The views expressed in this article are largely consistent with Orlova, "Russia's Anti-Money Laundering Regime". Orlova concludes that "Russian authorities have used the regime to attempt to reform the banking system and to extend their strategic control in the domestic political and business realms. The ineffectiveness of the AML regulations and their inconsistent application to achieve ulterior aims undermine the legitimacy of the regime as a whole."

31. It might be preferable to place less emphasis on suspicious activities reports, which require research and discretion by the financial institution, and assign greater emphasis to transactions above a certain amount, taking into account the countries involved in the transaction and the nature of the parties. A formula for this system could easily be developed and has the advantage not only of reducing errors in the course of deciding whether to file a report; it would also reduce the risk that money launderers could establish relationships with bank or regulatory employees to ensure that suspicious activities reports are not produced when the circumstances suggest that they should be.

32. "Central Bank Asks about Money Laundering," Kommersant, September 22, 2008, http:// www.kommersant.com/p1029744/r_500/money_laundering_organized_crime/ (accessed October 5, 2008).

33. Bruce Zagaris, "TF, Eurasian Group and Moneyval Evaluate Russian AML-CFT Progress," International Enforcement Law Reporter, September 2008. See also Bruce Zagaris, "International Money Laundering and Bank Secrecy," International Enforcement Law Reporter, December 2008.

34. Anatoly Medetsky, "Lack of Staff to Fight Money Launderers," Moscow Times, October 2, 2008.

35. Ibid.

36. "Russneft Wins Court Case," International Oil Daily, September 23, 2008.

37. "Russia Reports 7,000 Money Laundering Crimes in 2006-Ministry," Itar-Tass, October 26, 2006.

38. See Anders Aslund, Russia's Capitalist Revolution: Why Market Reform Succeeded and Democracy Failed (Washington, DC: Peterson Institute for International Economics, 2007); Edward Lucas, The New Cold War: The Future of Putin's Russia and the Threat to the West (New York: Palgrave Macmillan, 2008); Steve LeVine, Putin's Labyrinth: Spies, Murders, and the Dark Heart of the New Russia (New York: Random House, 2008); Lilia Shevtsova, Putin's Russia (Washington, DC: Carnegie Endowment for Peace, 2005); and Miriam Elder, "How the State Got a Grip on Energy," Moscow Times, March 14, 2008. See also "Russia's Largest Raw Material Companies May Be Nationalized," Vedomosti, November 8, 2006.

39. Lilia Shevtsova writes that "in the struggle for property, some law enforcement agencies are openly fighting others; the [MVD] has been pitched against the FSB, the FSB against the Tax 
Department, the latter against the [procurator]'s office, and so on. Federal and regional security officers confront each other in battle for the ownership of enterprises, the right to extract tribute from entrepreneurs, and for control of the banks. This battle, particularly in the regions, is conducted openly and is violent." Lilia Shevtsova, Russia Lost in Transition: The Yeltsin and Putin Legacies (Washington, DC: Carnegie Endowment for Peace, 2007), 101.

40. For a discussion of Putin's success, despite severe human rights violations, see Sergei Kovalev, "Why Putin Wins," New York Review of Books, November 22, 2007, 64-66. For evidence that behind the current facade is instability, see Lilia Shevtsova, "Think Again: Vladimir Putin," Foreign Policy, January/February 2008, http://www.foreignpolicy.com/users/login.php?story_ id=4093\&URL (accessed December 29, 2008).

41. Transparency International, "Corruption Perceptions Index 2007," Surveys and Indices, http://www.transparency.org/policy_research/surveys_indices/cpi/2007 (accessed July 11, 2008). See also Michael McFaul and Kathryn Stoner-Weiss, "The Myth of Putin's Success," Foreign Affairs, January/February 2008, 68-85.

42. The current oligarchs apparently are eager to reach accommodations with the Russian ruling elite. Perhaps that is a sign of pragmatism-if someone has been permitted to earn several hundred million dollars from owning a particular company, why not sell the company to an individual enjoying support from the authorities for half of its actual worth? Graham Stack, "Equally Distanced Oligarchs: Although the Kremlin Still Consults the Oligarchs, They Seem to No Longer Dictate Policy or Appointments," Russia Profile, May 22, 2008.

43. Ibid. See also Michael Freedman's discussion with Nikolay Borov of Berezovsky's attempts to destroy Putin's image after the president asserted his "independence" from his former patrol. Freedman, "Dark Forces," Forbes, May 21, 2007. For more on this subject, see Ethan S. Burger, Esq. and Mary Holland, "Law as Politics: The Russian Procuracy and Its Investigative Committee" (paper, New York University Public Law and Legal Theory Working Papers, Paper no. 108, 2008), http://lsr.nellco.org/cgi/viewcontent.cgi?article=1108\&context=nyu/plltwp (accessed February 3, 2008).

44. Anna Smolchenko, "United Russia Creates Post for Putin," Moscow Times, April 15, 2008.

45. Susan Rose Ackerman, Corruption and Government: Causes, Consequences and Reform (New York: Cambridge University Press, 1999), 190.

46. Andrei Illarionov, "Russia Inc.," New York Times, February 4, 2006.

47. Tatyana Netreba and Tatyana Kuznetsova, "Officials under a Glass Roof! Deep inside the Kremlin the Draft National Plan for Combating Corruption Is Almost Ready," interview with Aleksandr Anikin, Argumenty i Fakty, August 1, 2008.

48. See, for example, Raymond W. Baker, Capitalism's Achilles Heel: Dirty Money and How to Renew the Free-Market System (Hoboken, NJ: Wiley, 2005); Margaret E. Beare, ed., Critical Reflections on Transnational Organized Crime, Money Laundering and Corruption (Toronto: University of Toronto Press, 2003); Peter Reuter and Edwin M. Truman, Chasing Dirty Money and Roman Kupchinsky's "Crime, Corruption, and Terrorism Watch," formerly a regular report of Radio Free Europe/Radio Liberty, also includes numerous examples.

49. Shevtsova, Russia Lost in Transition, 118-31.

50. "Special Report: The World's Billionaires," Forbes.com, March 5, 2008, http://www.forbes .com/lists/2008/10/billionaires08_The-Worlds-Billionaires_CountryOfCitizen.html (accessed March 11, 2008).

51. Luisa Kroll and Allison Fass, "Special Report: The World's Billionaires," Forbes, March 8, 2007. See also Maria Rozhkova and Mikhail Overchenko, "87 Russians Made It to the Forbes List," Vedomosti, March 7, 2008, B1; and Max Delany, "Record 87 Russians on Forbes Rich List," Moscow Times, March 7, 2008.

52. "Number of Russian Billionaires Grows Ten-Fold in Decade-Official," Itar-Tass, March 26, 2008. Accounting Chamber Chairperson Sergey Stephasin considered this evidence of economic inequities, which he regarded as destabilizing. "Too Many Billionaires in Russia-Stepashin," Interfax, March 26, 2008.

53. See World Bank, Russian Energy Report, November 2007, http://siteresources.worldbank .org/INTRUSSIANFEDERATION/Resources/RER15_Eng.pdf (accessed March 11, 2008). 
54. Nikola Krastsev, "Russia: Youthful Billionaires Storm Forbes' List," Radio Free Europe/ Radio Liberty, March 9, 2007, http://www.rferl.org/content/Article/1075155.html (accessed February 3,2008$)$.

55. In April 2007, Deripaska was stripped of his U.S. visa in connection with his alleged ties to the Russian criminal world. See Jeffrey H. Birnbaum and John Solomon, "Aide Helped Controversial Russian Meet McCain; Davis, Then a Lobbyist, Has Spurred Debate in Reform-Focused Campaign," Washington Post, January 25, 2008, A-1; Andrew E. Kramer, "Out of Siberia, A Russian Way to Wealth," New York Times, August 20, 2006; "Oleg Deripaska Stripped Off [sic] U.S. Visa," Kommersant, April 20, 2007, http://www.kommersant.com/p-10583/r_500/Deripaska_U.S._visa/ (accessed March 11, 2008); and John Reed and Brian Reid, "Russian 'Rockefeller' Eyes Foreign Expertise," Financial Times, August 10, 2007, 23.

56. Kroll and Fass, "Special Report: The World's Billionaires." See also Marina Pustilnik, "A New Way to Beat the Summer Doldrums," Moscow Times, July 13, 2007. Not surprisingly, there are exceptions to all rules. Vladimir Yevtushenkov is believed to have in excess of $\$ 1$ billion. He is not a fan of the word "oligarch," and his wealth is the result of activities in communications and other high-tech areas. He may be the only Russian billionaire who did not become wealthy as a result of gaining control over natural resources or political connections--over time, future billionaires are almost certain to join him.

57. Pustilnik, "A New Way to Beat the Summer Doldrums."

58. Rozhkova and Overchenko, "87 Russians Made It to the Forbes List."

59. See, for example, Aslund, Russia's Capitalist Revolution, $252 \mathrm{n} 38$.

60. According to a Tass report, in 2006 the MVD and the Russian Tax Service prevented approximately 8,000 "fly-by-night" companies from being registered. "Creation of Over 8,000 Fly-ByNight Companies Averted in Moscow," Tass, February 21, 2007. There is no way to estimate the number of such entities that successfully registered in Russia or abroad. Indeed, it is possible to purchase a preformed legal entity in many jurisdictions merely by calling a company that offers such services, providing the information requested, and paying fees and registration costs. Companies also often offer such services as acting as nominal directors at an additional charge.

61. Shevtsova, Russia Lost in Transition, 10-11 and 154-59.

62. "Some 100,000 Russian Govt Officials Unlawfully Involved in Business Activities-Prosecutor," Interfax, February 19, 2008.

63. "Roman Abramovich Steps Down as Chukotka Governor," Pravda.ru, http://english.pravda .ru/news/russia/03-07-2008/105689-roman_abramovich-0 (accessed October 2, 2008).

64. Andrew Osborn, "The A-Z of Oligarchs," Independent, May 26, 2006, 1.

65. Adi Ignatius, "Person of the Year 2007: A Tsar Is Born," Time, December 31, 2007, 60.

66. Luke Harding, "Putin, the Kremlin Power Struggle and the \$40bn Fortune," Guardian, December 21, 2007, http://www.guardian.co.uk/world/2007/dec/21/russia.topstories3 (accessed January 12, 2009).

67. Anders Aslund, "Unmasking President Putin's Grandiose Myth," St. Petersburg Times, December 4, 2007. Aslund writes, "If these numbers contain any truth, Putin would be the most corrupt political leader in world history, easily surpassing Ferdinand Marcos of the Philippines and Zaire's Mobutu."

68. Pursuant to Section 312 of the USA PATRIOT Act of 2001, should proceeds from foreign corruption enter the U.S. banking system, they may be regarded as "laundered funds" by U.S. law enforcement and regulatory authorities, giving rise to criminal prosecutions of individuals, including foreign nationals, who do not enjoy immunity from prosecution in the United States, as incorporated at 31 U.S.C. § 5318(i). Financial Crimes Enforcement Network, "Fact Sheet," United States Department of the Treasury, http://www.fincen.gov/312factsheet.html (accessed March 3, 2008).

69. Glenn R. Simpson, "Russian Regulator under Fire, Virgin Islands Says Evidence Points to Telecom Holdings," Wall Street Journal, November 14, 2007, A8.

70. Stephen Fidler, "Bermuda Seeks to Liquidate Russian-Linked Companies," Financial Times, February 12, 2007, http://www.ft.com/cms/s/0/99a9d07c-bae1-11db-bbf3-0000779e2340 .html?nclick_check=1 (accessed August 13, 2008). 
71. Catherine Belton and Stephen Fidler, "US Told of 'Evidence' on Russian Minister," Financial Times, November 15, 2007. The article describes Reiman as a "Putin ally." See also Aslund, "Unmasking President Putin's Grandiose Myth"; and Robert Amsterdam, "Russia's Offshore Telecom Corruption Case," RobertAmsterdam.com, November 15, 2007, http://www.robertamsterdam .com/2007/11/russias_offshore_telecom_corru.htm (accessed August 13, 2008). Amsterdam, an attorney representing Russian oligarch Mikhail Khodorkovsky, maintains this Web site.

72. Stanislav Belkovksy argues that Putin chose Medvedev as his successor precisely "because one of the most important problems for the Putin government has not yet been solved_namely the legalization of the Russian politico-economic elite, its capital, in the West. Precisely for that reason Putin was forced to stake on a candidate with the image of a liberal, who will have a certain carteblanche from and credit of trust with the West." Quoted in Jonas Bernstein, "Stanislav Belkovsky: Putin Will Leave Power Completely," Eurasia Daily Monitor, November 19, 2007, http://www .jamestown.org/single/?no_cache=1\&tx_ttnews[tt_news]=33176 (accessed February 3, 2009).

73. Lyudmila Alexandrova, "Russian Govt Heads May Roll, but Not Earlier than March 2007," Tass, November 27, 2006. The Russian state-controlled Gazprom can rely on the Russian government to look out for its interests. See also Lyudmila Alexandrova, "Gazprom Takes over Sakhalin-2, while Sakhalin-1 Is under Scrutiny," Itar-Tass, April 19, 2007.

74. Shevtsova, Russia Lost in Transition, 125.

75. Andrei Sharov, "Yuri Chaika Counts on Defense," Agency WPS, January 11, 2008.

76. "Over 1,000 Senior Russian Officials Prosecuted in 2007-Chief Investigator," Interfax, February 19, 2008.

77. Yekaterina Zabrodina, "Russia's Anti-Corruption Drive Impeded by Selective Justice," Moscow News, December 8, 2006.

78. See generally the General Procuracy's Web site, available at http://eng.genproc.gov.ru/ in English and http://www.genproc.gov.ru in Russian.

79. For a fascinating, detailed account of state expropriation in Sverdlovsk, including a discussion of the role of the courts, see Anna Politkovskaya, "How to Misappropriate Property with the Connivance of the Government," in Putin's Russia: Life in a Failing Democracy (New York: Metropolitan Books, 2005), 114-59.

80. Catherine Belton and Ed Crooks, "BP Submits to Kremlin Pressure and Hands Kovykta to Gazprom," Financial Times, June 23, 2007, 1.

81. It is still not clear that the Russian government has intentionally acted to promote the Russian group Alfa Access Renova (AAR) in the TNK-BP case, although the Russian authorities' scrutiny of TNK-BP's taxes, imposition of small fines for alleged labor law violations, and refusal to grant visas to certain BP employees working on the joint venture may be more than a coincidence. AAR is owned by Mikhail Fridman, German Khan, Viktor Vekselberg, and Len Blavatnik, among others. Catherine Belton, Ed Crooks, and Jim Pickard, "Russia to Speed Up TNK-BP Visas'Renewal," Financial Times, July 1, 2008, http://www.ft.com/cms/s/0/454bf7f8-4898-11dd -a851-000077b07658.html (accessed January 12, 2009); Irina Bogdanova, "TNK-BP CEO Fined $\$ 125$ for Breaking Russian Labor Code Rules," RIA Novosti, June 23, 2008; "Joint Aversion: BP Demands \$352 Mln from Russian TNK-BP Shareholders," Kommersant, July 7, 2008, http://www .kommersant.com/p909848/r_529/BP_demands_compensation_from_AAR/ (accessed January 12, 2009); and Andrew Osborn and Guy Chazan, "BP Venture in Russia Hit as CFO Steps Down," Wall Street Journal, August 5, 2008, A1.

82. Andrew E. Kramer, "The Kremlin Flexes, and a Tycoon Reels," New York Times, July 8, 2007, http://www.nytimes.com/2007/07/08/business/yourmoney/08nickel. (accessed August 13, 2008).

83. Carola Hoyos, "A New Era of Nationalism," Financial Times, June 19, 2007, 2.

84. Catherine Belton, "Glencore Makes a Move on RussNeft," Financial Times, October 25, 2007, 20; and "Russia Starts to Pay Price for Its Energy Strategy," Financial Times, April 21, 2008, 4.

85. Toby Shelley, "Siberia Oil Field Helps Sibir Lift Output by $80 \%$," Financial Times, February 7 , $2008,21$.

86. Megan Murphy, "Russian Oligarchs Square Up for $£ 2 b n$ Court Fight," Financial Times, April 19, 2008, 4. Berezovsky sued Abramovich, who also lives in London, in connection with this transaction. 
87. Catherine Belton, "Rosneft Set for Final Section of Yukos Jigsaw in South of Russia, Financial Times, August 3, 2007, 13.

88. It will be years before definitive works on the fall of Yukos will be produced by disinterested individuals, and even when such books appear, there will always be the question of incomplete information. The New York Times maintains an archive of its stories about Yukos. "Yukos," New York Times, http://topics.nytimes.com/top/reference/timestopics/organizations/y/yukos/index.html (accessed November 26, 2007). See also Shevtsova, Putin's Russia, 275-82; Catherine Belton, "Khodorkovsky Defense Seeks Chevron Subpoena," Financial Times, August 31, 2007, 21; Clifford J. Levy, "Swiss Reject Request for Yukos Records," New York Times, August 25, 2007, A7; and Anton Troianovsky, "Swiss Court: Yukos Case Is 'Political," Washington Post, August 25, 2007, A11. Troianovsky notes the Swiss Supreme Court's decision to reject the Russian General Procuracy's request for legal assistance. This ruling described the Russian government's pursuit of Khodorkovsky as "politically motivated" and designed to "go after a class of rich oligarchs and push aside . . p political adversaries." According to Levy, the Swiss High Court views the Procuracy's actions as constituting an abuse of power. Troianovsky characterizes the court's decision as a "rebuke" to the Kremlin. The decision may reduce the likelihood that future Western judges will grant comity to Russian courts' decisions in high-profile cases.

89. "Russia \& CIS Business and Financial Newswire," Interfax, December 28, 2006.

90. McFaul and Stoner-Weiss, "The Myth of Putin's Success, 82 (see n41).

91. Catherine Belton, "The State's Unsaturated Appetite: By May, the Government's Share of Crude Output Could Reach 55 Per Cent," Financial Times, April 20, 2007, 4.

92. Catherine Belton and Neil Buckley, "Steeled to Succeed-Ivanov Sets Out His Tough Vision for Russia's Future," Financial Times, April 19, 2007, 15.

93. "Russia's Velvet Reprivatization: Interview with Oleg Shvartsman," Kommersant, November 30, 2007, http://www.kommersant.ru/doc.aspx?DocsID=831089 (accessed January 12, 2009). For an English translation, see Robert Amsterdam, "Russia's Velvet Re-Privitization," RobertAmster dam.com, http://www.robertamsterdam.com/2007/11/russias_velvet_reprivatization.htm (accessed August 13, 2008).

94. "Russia's Velvet Reprivatization: Interview with Oleg Shvartsman."

95. Federal Law, On the Procedure for Making Foreign Investments in Economic Companies Which Are of Strategic Importance for Ensuring the Country's Defense Capacity and State Security, April 29, 2008.

96. Some legal scholars, such as George Ginsburgs, have noted that although Russia has participated in the Council of Europe's International Court of Human Rights, the extent to which Russian authorities will allow international law obligations to override domestic law remains uncertain. Ginsburgs, From Soviet to Russian International Law: Studies in Continuity and Change Law in Eastern Europe (New York: Springer, 1998), 1-146.

97. FATF maintains an excellent Web site that deals with all aspects of combating money laundering: "FATF-GAFI," Financial Action Task Force-General Authority for Investment (FATF-GAFI), http://www.fatf-gafi.org/pages/0,2987,en_32250379_32235720_1_1_1_1_1,00.html (accessed October 3, 2008).

98. FATF, "General Information Russia," FATF-GATI, http://www.fatf-gafi.org/document/60/ 0,3343,en_32250379_32236869_36100796_1_1_1_1,00.html (accessed October 5, 2008). This Web page is devoted to Russia and contains excellent information and useful links.

99. See FATF, "FTAF Membership Policy," FATF-GAFI, February 29, 2008, http://www.fatf-gafi .org/dataoecd/25/48/41112798.pdf (accessed October 5, 2008).

100. FATF, "FATF-GAFI."

101. Predicate offenses are crimes from which the proceeds are laundered. Some crimes are deemed predicate offenses only when committed in the country in which an individual is charged with money laundering. For example, according to this revenue rule, in most cases, tax evasion in a foreign country may not serve as a predicate offense. Pasquantino v. United States, 544 U.S. 349 (2005).

102. FATF, "Summary of the Second Mutual Evaluation Report: Anti-Money Laundering and Combatting the Financing of Terrorism, Russian Federation," FATF-GATI, June 20, 2008, http:// www.fatf-gafi.org/dataoecd/51/27/40945440.pdf (accessed February 3, 2008). 
103. Developing an effective system of identifying individuals could curb money laundering. Currently, false identifies can be easily created and agents can act on behalf of a PEP.

104. Financial Action Task Force, "Summary of the Second Mutual Evaluation Report."

105. FATF "Second Mutual Evaluation Report," paragraphs 5, 8, 23, 32, and 39.

106. "Russia Financial Watchdog Recognized as One of the Best in the World," SKRIN Market \& Corporate News, August 11, 2008.

107. "FATF Ranks Russia among 5 Worst Performers in Laundering Prevention," Prime-Tass, July $3,2008$.

108. See, for example, Michael Peel, "The Dark Side of London's Success," Financial Times, December 6, 2007, 16. Peel discusses how banking professionals facilitate financial crimes by foreigners.

109. See Baker, Capitalism's Achilles Heel, 1-161 (See n48). Baker discusses the role of "dirty money" in the world economy.

110. Many persons who have no qualms facilitating routine money laundering are far less likely to cooperate if they fear that terrorist financing may be involved.

111. Ed Lucas, "Do Not Let Russia 'Finlandise' Western Europe," Financial Times, October 9, 2008; Marshall I. Goldman, Petrostate: Putin, Power and the New Russia (New York: Oxford University Press, 2008); and Energy Information Administration, "Country Analysis Briefs: Europe," http://www.eia.doe.gov/emeu/cabs/Region_eu.html (accessed October 10, 2008).

112. Andrew E. Kramer, "Austrians Cast Doubt on Russian Arrests in Murder Case," New York Times, June 15, 2007, http://www.nytimes.com/2007/06/15/world/europe/15moscow.html (accessed October 7, 2008).

113. Senate Permanent Subcommittee on Investigations, Suspicious Banking Activities: Possible Money Laundering by U.S. Corporations Formed for Russian Entities, report prepared by General Accounting Office, 106 Cong., 2d sess., October 2000, GAO-01-120.

114. Ibid., 1.

115. Ibid., 2.

116. U.S. bankers working at Riggs Bank in Washington, DC, laundered billions of dollars from the embassy personnel of Saudi Arabia and Equatorial Guinea and from former Chilean dictator Augusto Pinochet during the 1990s. Riggs Bank personnel simply did not comply with AML regulations from the Bank Secrecy Act. Senate Permanent Subcommittee on Investigations, "Money Laundering and Foreign Corruption Enforcement and the Effectiveness of the Patriot Act," 108th Cong., 2d sess., July 15, 2004, S. Hrg. 108-633, http://hsgac.senate.gov/public/_files/ACF5F8.pdf (accessed February 3, 2008).

117. Anton Zaritovskiy, "Russian Banks Laundering Hundreds of Billions of Rubles," Izvestia, October 7, 2008.

118. For more details of the rivalry between the General Procuracy and the Investigative Committee, and the Kremlin's unwillingness to resolve the problems that have arisen as a result of the creation of the latter body, see Yevgenia Zubchenko, Marjam Magomedova, and Kira Vasilieva, "Above Fight," Novye Izvestia, June 10, 2008, 2.

119. Konstantin Gaaze, Artyom Vernidub, and Mikhail Fishman, "Dealing with Crooks," Russian Newsweek, June 9, 2008, 17-20.

120. Alexander Sadchikov, "Four Strikes at Corruption," Izvestia, June 26, 2008, 1.

121. Federalnyi Zakon No. 273-FZ, O protivodeistvii korruptsii, December 25, 2008; and Federalnyi Zakon No. 274-FZ, O vnesenii izmenenii v otdelnye zakonodatelnye akty Rossiiskoi Federatsii v sviazi s priniatiem Federalnyi Zakon No. 273-FZ "O protivodeistvii korruptsii Federalngo Zakona "oprotivo deistvy korruptsy"" [Federal Law No. 273 "On the Introduction of Changes in Separate Legislative Acts of the Russian Federation in Connection with the Adoption of Federal Law No 273-FZ 'On Counteracting Corruption'"], December 25, 2008; in addition there are two separate sets of corrections to the first law and one for the second law. A page of the Russian president's Web site is devoted to new legislation in this area and is available at http://www.kremlin. $\mathrm{ru} /$ text/news/2008/12/211017.shtml (accessed January 29, 2009).

122. "War on Corruption ... Is Impossible without Civil Society and Free Media," Nezavisimaya Gazeta, June 5, 2008, 2. 